\title{
Bioactivity enhancement of calcined kaolin geopolymer with $\mathrm{CaCl}_{2}$ treatment
}

\author{
Saengsuree Pangdaeng ${ }^{\mathrm{a}}$, Vanchai Sata ${ }^{\mathrm{b}}$, J.B. Aguiar ${ }^{\mathrm{c}}$, F. Pacheco-Torgal ${ }^{\mathrm{c}}$, Jarin Chindaprasirt ${ }^{\mathrm{d}}$, \\ Prinya Chindaprasirt ${ }^{\mathrm{b}, *}$ \\ a Division of Civil Engineering, Faculty of Engineering, Nakhon Phanom University, \\ Nakhon Phanom 48000 Thailand \\ b Sustainable Infrastructure Research and Development Centre, Department of Civil Engineering, \\ Faculty of Engineering, Khon Kaen University, Khon Kaen 40002 Thailand \\ c C-TAC Research Centre, Department of Civil Engineering, University of Minho, Campus of Azurém, \\ 4800-058, Guimarães, Portugal \\ d Department of Internal Medicine, Faculty of Medicine, Khon Kaen University, Khon Kaen 40002 Thailand
}

*Corresponding author, e-mail: prinya@kku.ac.th

Received 25 Sep 2015

Accepted 24 Dec 2016

\begin{abstract}
This paper reports that surface treatment with $\mathrm{CaCl}_{2}$ enhances the bioactivity of a calcined kaolin geopolymer. Calcined kaolin, $\mathrm{NaOH}$ solution, sodium silicate solution, and heat curing were used to form geopolymer pastes. A soaked-treatment method was applied to the geopolymer samples using $\mathrm{CaCl}_{2}$ solution as the ion exchange agent. The bioactivity of the material was determined by the simulated body fluid (SBF) in vitro testing method. Scanning electron microscope images showed a dense apatite formation on the treated geopolymer surface after SBF immersion for only 3 days. The $\mathrm{CaCl}_{2}$ treatment promoted compressive strength and enhanced bioactivity by accelerating apatite precipitation and slowing down the rise in $\mathrm{pH}$.
\end{abstract}

KEYWORDS: aluminosilicate, metakaolin, apatite, SBF

\section{INTRODUCTION}

A geopolymer is an aluminosilicate amorphous structure that results from the polycondensation of inorganic compounds ${ }^{1}$. A geopolymer is defined as an alkali-activated material and is produced through the reaction of aluminosilicate materials with an alkaline activator, which is usually a concentrated alkali hydroxide, silicate, carbonate, or sulphate ${ }^{2}$. Fly ash, ground granulated blast furnace slag, and calcined kaolin are good source materials. Geopolymers can be produced and used as a cementitious material similar to Portland cement as they are strong and durable. Research on the use of geopolymers has been extended to many fields such as fire resistant construction materials ${ }^{3}$, and smart materials ${ }^{4}$.

Cementitious materials have various applications such as sensing and electrical components ${ }^{5}$, self-cleaning material with photo catalysis properties $^{6}$, and biocompatible materials ${ }^{7-9}$. Cement and ceramic have been studied in application of biocompatible material and generally used as "in vitro" test method, the outside body test using simulated body fluid (SBF) ${ }^{10,11}$. The use of mechanically compliant interface with living tissue was first observed in 1969 and is now referred as 'bioactivity' ${ }^{12}$. Bioactivity of implant materials is usually identified by precipitation of biolayer on material surface called apatite layers ${ }^{13}$. These biocompounds are connectable bonding between material and living bone and play significant role in nucleation sites for new bone growth ${ }^{14}$. Apatite layers are commonly composed of calcium and phosphate such as $\mathrm{Ca}_{10}\left(\mathrm{PO}_{4}\right)_{6}(\mathrm{OH})_{2}$ hydroxyapatite (HA), $\mathrm{Ca}_{10}\left(\mathrm{PO}_{4}\right)_{6}\left(\mathrm{CO}_{3}\right)\left(\mathrm{H}_{2} \mathrm{O}\right)$ carbonate apatite, and $\mathrm{Ca}_{10}\left(\mathrm{PO}_{4}\right)_{6} \mathrm{Cl}_{2}$ chlorapatite ${ }^{15}$. Furthermore, the change in $\mathrm{pH}$ condition of SBF solution after soaking the material has an important effect on the biocompatibility. High $\mathrm{pH}$ changes at the surface of the implant material can harm living cells ${ }^{16}$.

Recently, biocompatible metakaolin-aluminosilicate materials have been tested both in vivo ${ }^{17-19}$ and in vitro ${ }^{20-23}$. For implant applications ${ }^{24}$, geopolymers have been shown to be bioactive with low ion leakage, although the possible leaching of aluminium can result in toxicity ${ }^{21}$. Kaolinite, a good source material for making geopolymers, has been 
extensively used as a pharmaceutical excipient. The study of geopolymers for implant material indicates the problem of low bioactivity. The incorporation of $\mathrm{Ca}(\mathrm{OH})_{2}$ in geopolymers can promote the apatite forming ability ${ }^{21}$. The presence of $\mathrm{CaCO}_{3}$ enhances the apatite forming ability by inducing the precipitation of phosphate ions ${ }^{10} \cdot \mathrm{CaCl}_{2}$ and white Portland cement produce nontoxic treated cement paste $^{8}$, and increase the bioactivity by showing high hydroxyapatite formation after immersion in SBF solution ${ }^{25}$. For geopolymer material, adding of $\mathrm{CaCl}_{2}$ can be applied in a small amount around $1 \%$ of binder because of the rapid hardening ${ }^{26}$ and is not sufficient to gain high bioactivity. Since geopolymer structure has a weak sodium bond and this can be leached out almost completely ${ }^{27}$, thus it can be charge-balanced with other cations by treating with chloride solution of the desired cations ${ }^{28}$. Direct contact of $\mathrm{CaCl}_{2}$ solution provides $\mathrm{Ca}^{2+}$ cations to the surface of geopolymer and promotes the precipitation of reactive calcium compound for bioactivity and simultaneously enhances strength and durability of geopolymers ${ }^{29}$.

This paper presents the use of $\mathrm{CaCl}_{2}$ to enhance the apatite forming ability of calcined kaolinite geopolymer. The knowledge would be instrumental for future development of calcined kaolinite geopolymer for biomaterial applications.

\section{MATERIALS AND METHODS}

\section{Materials}

Kaolin from Ra Norng province in southern Thailand was calcined at $600^{\circ} \mathrm{C}$ for $6 \mathrm{~h}$ to generate high reactivity calcined kaolin (CK) ${ }^{30}$ and used as a source material. The $\mathrm{CK}$ consisted of $60 \% \mathrm{SiO}_{2}, 34 \% \mathrm{Al}_{2} \mathrm{O}_{3}$, $0.1 \% \mathrm{CaO}, 0.9 \% \mathrm{Fe}_{2} \mathrm{O}_{3}, 0.2 \% \mathrm{MgO}, 0.2 \% \mathrm{Na}_{2} \mathrm{O}$, $0.1 \% \mathrm{SO}_{3}$, and $1 \% \mathrm{LOI}$. $\mathrm{NaOH}$ with concentration of 10 molar and sodium silicate with $15 \% \mathrm{Na}_{2} \mathrm{O}, 33 \%$ $\mathrm{SiO}_{2}$, and $52 \% \mathrm{H}_{2} \mathrm{O}$ were used as alkali activators. $\mathrm{CaCl}_{2}$ solution (CC) with 0.5 molar concentration prepared from $\mathrm{CaCl}_{2} \cdot 2 \mathrm{H}_{2} \mathrm{O}$ and deionized water was used for treatment ${ }^{31}$. For the biocompatibility test, a simulated body fluid solution (SBF) with ion concentration similar to human blood plasma ${ }^{13}$ was prepared and used.

\section{Sample preparation}

Prepared CK was mixed with $\mathrm{NaOH}$ for 5 min and then mixed with sodium silicate for another $5 \mathrm{~min}$. The sodium silicate: $\mathrm{NaOH}$ ratio of 1 and liquid to binder ratio of 1 were used. Geopolymer paste was cast into $25 \times 25 \times 25 \mathrm{~mm}$ acrylic moulds for compressive strength test and $10 \mathrm{~mm}$ diameter and $2 \mathrm{~mm}$ thick disks for bioactivity test. The fresh geopolymer pastes were compacted for $10 \mathrm{~s}$ with the aid of a vibrating table. The moulds were left in a controlled $23^{\circ} \mathrm{C}$ room for $1 \mathrm{~h}$, and then wrapped with plastic film and cured at $60^{\circ} \mathrm{C}$ for $24 \mathrm{~h}$. The specimens were left to cool down and demoulded. For the control samples, they were also wrapped with plastic film and kept in the controlled $23^{\circ} \mathrm{C}$ room. For $\mathrm{CaCl}_{2}$ treatment, the samples were treated by soaking in CC solution for $24 \mathrm{~h}$ at $23^{\circ} \mathrm{C}^{32}$. The samples were then dried in a desiccator for $12 \mathrm{~h}$ and wrapped with plastic film and stored in the controlled $23^{\circ} \mathrm{C}$ room.

\section{In vitro test}

At the age of 7 days, the treated and untreated discs were soaked in SBF solution with solution volume to sample surface of $0.1^{33}$. The immersed duration was left for 28 days with temperature controlled at $37^{\circ} \mathrm{C}$ similar to human body ${ }^{13}$. The $\mathrm{pH}$ values of SBF solutions were monitored during the soaking.

\section{Other tests}

Geopolymers were tested for compressive strength at 7 days in accordance with ASTM C109 ${ }^{34}$. The reported results are the average of three samples. Bioactivity characterization of geopolymer surface was made using JEOL JEM-5910LV scanning electron microscopy (SEM). Identification of $\mathrm{pH}$ change after sample immersed in SBF was done by ion electrode $\mathrm{pH}$ meter. The X-Ray Diffraction (XRD) experiments were performed with step of $0.0229^{\circ}$ and step time of $240.5 \mathrm{~s}$ at $25^{\circ} \mathrm{C}$ using Bruker's TOPAS software to confirm the chemical compound of geopolymer. Fourier transform infrared (FTIR) spectroscopy was also performed on the geopolymer samples.

\section{RESULTS AND DISCUSSION}

\section{Compressive strength and surface structure}

The 7 days compressive strength of control and treated pastes were 49.9 and $53.7 \mathrm{MPa}$, respectively. These strength values are comparable to the other reported compressive strengths of calcined kaolinite geopolymers ${ }^{35,36}$. The treatment by $\mathrm{CaCl}_{2}$ had a positive effect on the strength development. The increase of strength was due partly to the additional wet curing of the samples soaked in the $\mathrm{CaCl}_{2}$ solution. The immersion caused sustained water on the surface of geopolymer and affected the geopolymerization ${ }^{37}$. Moisture curing of geopolymer results 

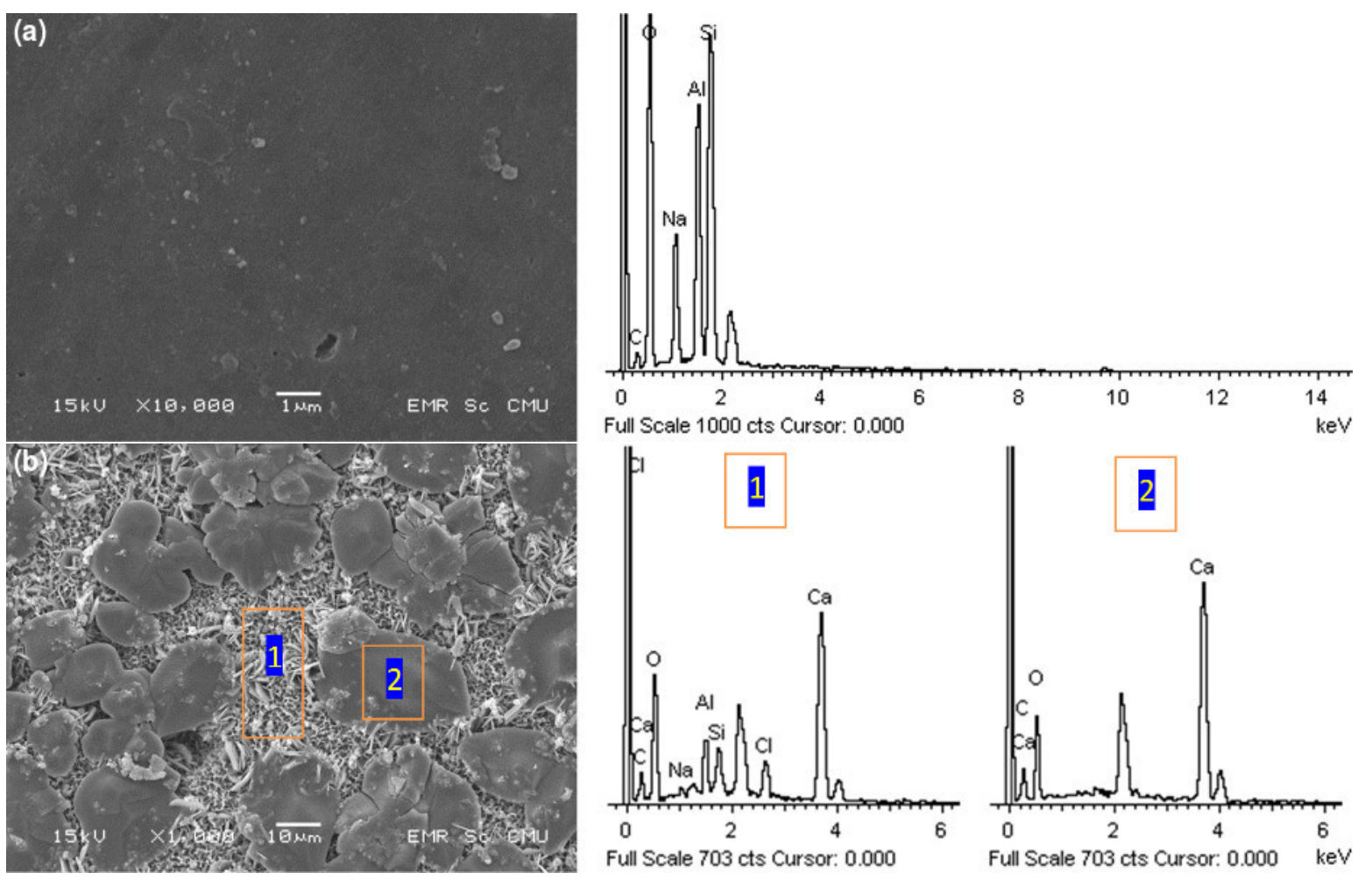

Fig. 1 SEM images of geopolymer surfaces before soaked in SBF solution; (a) control sample, (b) treated sample.

in a slight increase in strength compare to ambient curing condition ${ }^{38}$. Immersion of geopolymer in $\mathrm{CaCl}_{2}$ solution increased the amount of calcium ion absorption and the chemically bonds with geopolymer components similar to the behaviour of cement material ${ }^{31,32}$. The surface hardness of the geopolymer was improved due to the ions chargebalancing between $\mathrm{Ca}^{2+}$ and $\mathrm{Na}^{+}$cations. The calcium component consequently precipitated and improved surface hardness. This thus favourably affected the strength development of geopolymer paste.

The results of the SEM studies on the geopolymer surfaces are shown in Fig. 1. The surface of control paste was relatively smooth with EDS spectra of $\mathrm{Si}, \mathrm{Al}, \mathrm{O}$, and $\mathrm{Na}$ elements (Fig. 1a). These elements are the composition of kaolinite geopolymer ${ }^{36,39}$. After $\mathrm{CaCl}_{2}$ treatment, the surface structures showed the clear deposits of calcium compounds as shown in Fig. 1b with two different crystallized forms. The first form was the tiny crystals in area 1 which were the plates of calcium and chloride compounds precipitated in the geopolymer structure. Related EDS spectra showed mainly high peaks of $\mathrm{Ca}$ and $\mathrm{Cl}$ and low content of $\mathrm{Na}, \mathrm{Si}, \mathrm{Al}$, and $\mathrm{C}$ elements. The second form was the large crystal plate in area 2 which was identified as $\mathrm{CaCO}_{3}$ by the EDS spectra of $\mathrm{Ca}, \mathrm{C}$, and $\mathrm{O}$ elements and by high peak of calcite in XRD patterns in Fig. 2. The results thus show that $\mathrm{CaCl}_{2}$ was absorbed on kaolinite geopolymer surface by solution soaking. The followon induced carbonation reaction with $\mathrm{CO}_{2}$ from the atmosphere resulted in the formation of $\mathrm{CaCO}_{3}$ at the paste surface ${ }^{26}$ :

$$
\mathrm{CaCl}_{2}+\mathrm{CO}_{2}+\mathrm{H}_{2} \mathrm{O} \longrightarrow \mathrm{CaCO}_{3}+2 \mathrm{HCl}
$$

The weak sodium can be leached out from the geopolymer structure ${ }^{27}$ and charged-balance with calcium cations from $\mathrm{CaCl}_{2}{ }^{28}$. This phenomenon promotes $\mathrm{Ca}^{2+}$ to form at the surface of geopolymer in the form of reactive calcium compounds and enhances the strength development ${ }^{29}$. The use of $\mathrm{CaCl}_{2}$ promotes the strength of geopolymer and the biocompatible layers on geopolymer surface and thus results in a strong interfacial zone between geopolymer and new growth apatite.

\section{Apatite formation after SBF immersion}

The surface characteristic of geopolymer after soaking in SBF solution is presented in Fig. 3. For the control mix, the apatite-like layer formed after 


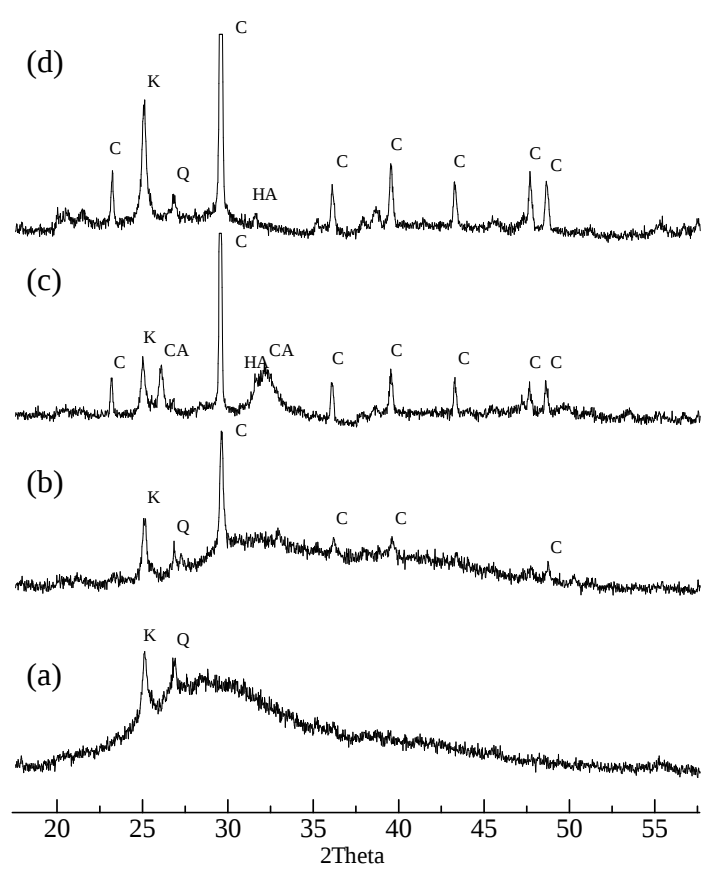

Fig. 2 XRD patterns of geopolymer paste discs; (a) control; (b) treated sample; (c) treated sample after 3 days in SBF; (d) treated sample after 28 days in SBF.

28 days of immersion was still not clearly visible (Fig. 3a), but the EDS spectra presented $\mathrm{Ca}$ and $\mathrm{P}$ as possibly precipitated from SBF solution. Geopolymer without $\mathrm{CaCl}_{2}$ treatment was poor in bioactivity due to the lack of $\mathrm{Ca}^{2+}$ ions to act as nucleation sites for apatite precipitation. For the $\mathrm{CaCl}_{2}$ treated geopolymer after 3 and 28 days of soaking in SBF, spherical particles of approximately $10 \mu \mathrm{m}$ in diameter of apatite phase were clearly observed covering the entire paste surface (Figs. $3 \mathrm{~b}$ and $3 \mathrm{c}$ ). The $\mathrm{Ca} / \mathrm{P}$ molar ratio from EDS analysis was 1.51 and 1.56 represented precipitated HA and/or $\beta$-tricalcium phosphate $(\beta-\mathrm{TCP})^{40,41}$. The morphology of the formed bioapatite layer was similar to the other published results ${ }^{42,43}$. The crystallographic study by XRD technique presented in Fig. 2 indicated the high amount of observed hydroxyapatite and chlorapatite on the $\mathrm{CaCl}_{2}$ treated sample after soaked in $\mathrm{SBF}$. The pattern of observed hydroxyapatite crystal in X-ray patterns was similar to the previous published results ${ }^{44}$. The X-ray pattern also displayed high $\mathrm{CaCO}_{3}$ peak at $29.5^{\circ} 2 \theta$ which correlated well with the FTIR result. The presence of high $\mathrm{CaCO}_{3}$ at the geopolymer surface is very positive in promoting the high apatite precipitation ${ }^{11}$. This showed that calcium compound especially $\mathrm{CaCO}_{3}$ deposited on the geopolymer surface as a result of

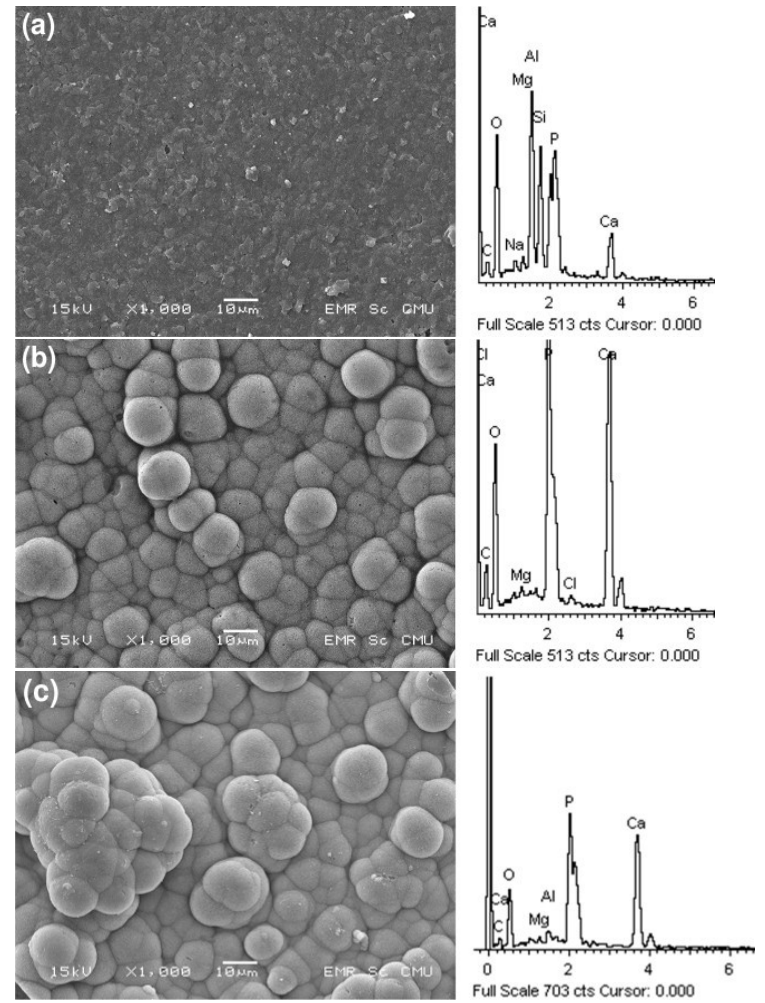

Fig. 3 SEM images of geopolymer surfaces after soaked in SBF solution; (a) control sample after 28 days in SBF solution; (b) treated sample after 3 days in SBF solution; (c) treated sample after 28 days in SBF solution.

$\mathrm{CaCl}_{2}$ treatment ${ }^{10}$. Metakaolin geopolymer without calcium treatment exhibited only a small apatite forming after immersion for 21 days ${ }^{45}$. The treatment by $\mathrm{CaCl}_{2}$ improved the forming of apatite as dense apatite was formed after only 3 days of soaking in SBF compared to the 7 days of soaking for calcium rich white cement ${ }^{46}$. The fast forming of hydroxyapatite is considered advantageous for implant materials ${ }^{47,48}$.

The EDS spectra as shown in Fig. 3 suggested the forming of dendrite of carbonate substituted hydroxyapatite $^{49}$ which was rich in $\mathrm{Ca}, \mathrm{P}, \mathrm{C}, \mathrm{Cl}$, and $\mathrm{Mg}$ similar to glass ceramic systems ${ }^{50}$. Side view of apatite growing by SEM image as shown in Fig. 4 showed the interfacial zone of geopolymer and formed apatite. Microstructure of geopolymer matrix on the left showed a dense surface with platy shape of kaolinite as also reported elsewhere ${ }^{51}$. The apatite structure on the right was very dense and covered the thickness around $15 \mu \mathrm{m}$. The side view clearly identified the good apatite forming and 

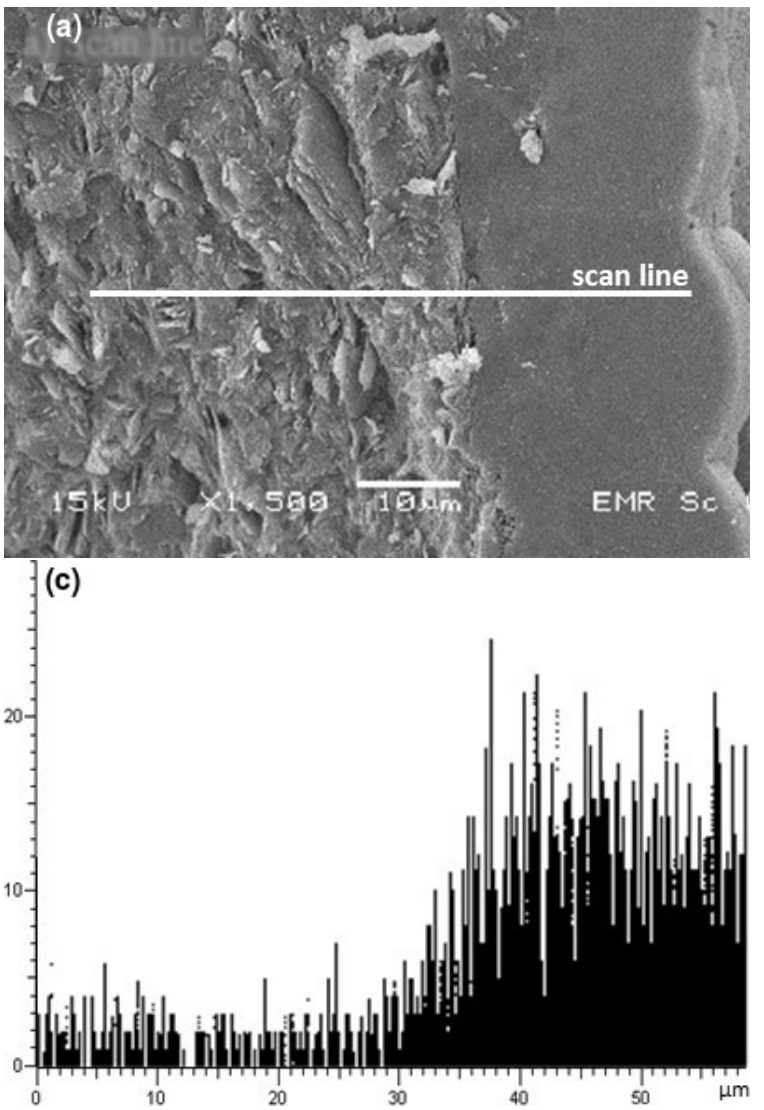

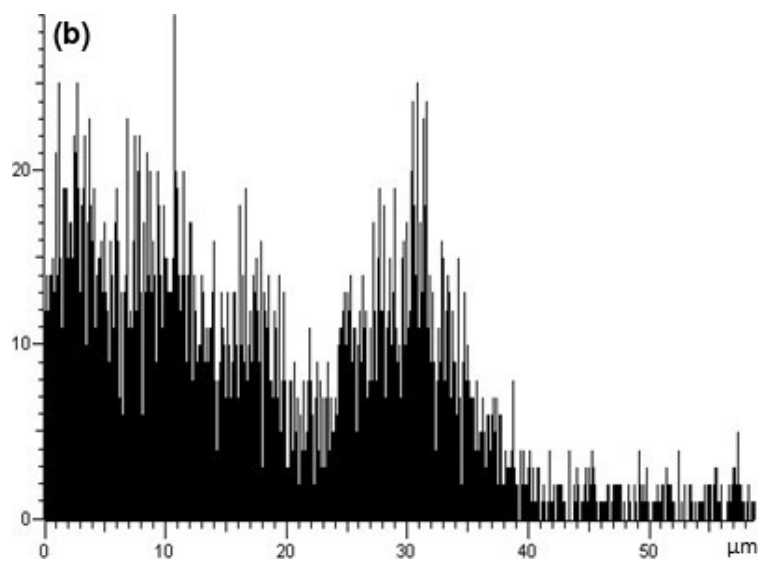

(d)

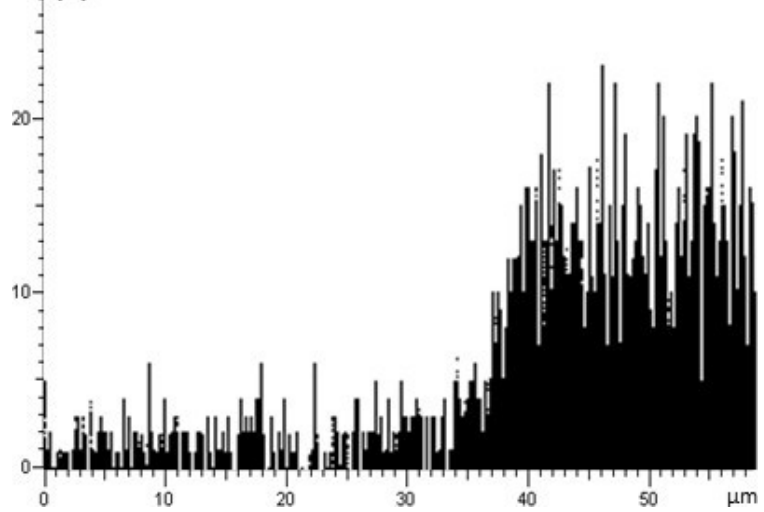

Fig. 4 (a) Side view of apatite forming by SEM and line analysis of (b) Si, (c) Ca, and (d) P.

interface bonding. Additionally, the line analysis showed distributions of important elements, viz., $\mathrm{Ca}, \mathrm{P}$, and $\mathrm{Si}$ across the transition zone. For $\mathrm{Ca}$ and $\mathrm{P}$, spectrum line peak raised at transition zone of geopolymer and apatite layer was clearly evident and the results correlated well with the SEM image. For $\mathrm{Si}$, the spectrum showed migration of Si by illustrating the spectrum dropped towards the transition zone and increased again at the transition zone. When material came into contact with SBF solution, the $\mathrm{Si}-\mathrm{OH}$ rich layer was formed and supported the migration of $\mathrm{Ca}^{2+}$ ions to be incorporated with $\mathrm{PO}_{4}{ }^{3-}$ ions from SBF solution and formed calcium rich film which continuously precipitated as apatite layer ${ }^{52,53}$. It had also been shown that the high reactivity of apatite forming produced a thick silica gel layer between the apatite layer and the glass material ${ }^{54}$. The FTIR spectra of geopolymer after 28 days soaking in SBF solution is shown in Fig. 5. $\mathrm{CaCl}_{2}$ treated sample presented $\mathrm{PO}_{4}{ }^{3-}$ band peak at $1030 \mathrm{~cm}^{-1}$ and apatitic $\mathrm{PO}_{4}^{3-}$ at 620 and $578 \mathrm{~cm}^{-1}$. The phosphate absorption bands of PO (cryst) of $\mathrm{PO}_{4}{ }^{3-}$ indicated the formation of apatite ${ }^{55,56}$. The presence of high PO band peak confirmed the enhancement of apatite precipitation on geopolymer surface with $\mathrm{CaCl}_{2}$ treatment. The SBF soaking of 28 days significantly showed higher band peak size of $\mathrm{PO}$ at the wavenumber around $1030 \mathrm{~cm}^{-1}$ than 3 days of soaking which represented the additional precipitation of apatite layer on sample surface with time. Moreover, treated sample showed the bending vibration peak of $\mathrm{CO}$ at $870 \mathrm{~cm}^{-1}$ corresponding to $\mathrm{CO}_{3}{ }^{2-}$ functional group of $\mathrm{CaCO}_{3}$. The presence of $\mathrm{CaCO}_{3}$ was an indication of the promotion of apatite forming. For untreated samples, no apatitic or $\mathrm{CaCO}_{3}$ band peaks were significantly observed. Similarly, the SEM results showed no crystalline shape in the untreated sample.

The $\mathrm{pH}$ of the SBF solution after soaking for up to 28 days is shown in Fig. 6. Measured pH value of SBF solution increased from 7.40-7.81 for untreated paste. For the paste with $\mathrm{CaCl}_{2}$ treatment, the increase in $\mathrm{pH}$ value was smaller at 7.59. This finding was in line with the other published results which reported the lower $\mathrm{pH}$ values of SBF solution for the $\mathrm{CaCl}_{2}$ treated samples than those of other 


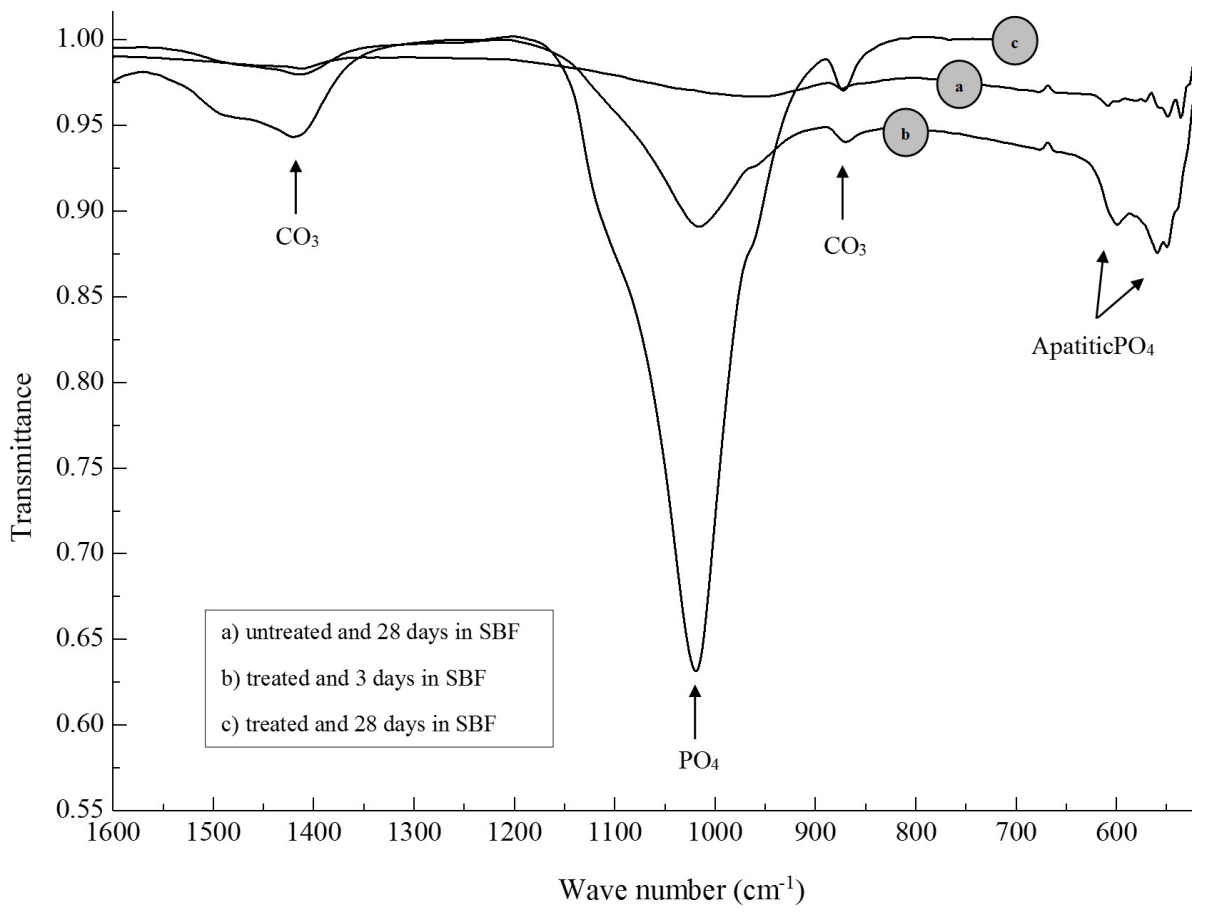

Fig. 5 FTIR spectra of geopolymer surface.

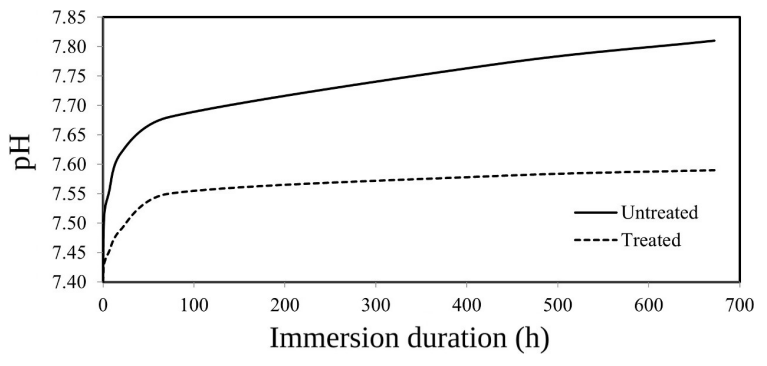

Fig. $6 \mathrm{pH}$ of SBF solution immersed with geopolymer discs.

cementitious materials ${ }^{10,57}$. The $\mathrm{pH}$ increase was a typical result of leaching of $\mathrm{NaOH}$ from material to SBF solution. The treatment process possibly reduced leaching ability of $\mathrm{NaOH}$ due to the forming of calcium compound layer. It can be concluded that $\mathrm{CaCl}_{2}$ treatment of geopolymer samples lowers the $\mathrm{pH}$ of the immersed solution and additionally promote the geopolymer surface for the growth of apatite.

\section{CONCLUSIONS}

Treatment of calcined kaolin geopolymer surface by soaking in 0.5 molar concentration of $\mathrm{CaCl}_{2} \cdot 2 \mathrm{H}_{2} \mathrm{O}$ solution for $24 \mathrm{~h}$ can embed calcium, chloride, and carbonate compounds to the material surface.
These reactive calcium rich layers promote the apatite precipitation. A good apatite forming on treated calcined kaolin geopolymer surface was obtained after 3 days in SBF immersion. The $\mathrm{CaCl}_{2}$ treatment not only enhances the early compressive strength by the process of moist curing but also renders low $\mathrm{pH}$ induction after the contact with SBF solution. This high rate of apatite forming and low alkalinity are preferable for the implant material.

Acknowledgements: This work was financially supported by the Higher Education Research Promotion and National Research University Project of Thailand, Office of the Higher Education Commission, through the Advanced Functional Materials Cluster of Khon Kaen University; and Khon Kaen University and the Thailand Research Fund (TRF) under the TRF-Royal Golden Jubilee Ph.D. program (Grant no. PHD/0143/2554); Post-doctoral training program (Grant no. 58110), Graduate school, Khon Kaen University and TRF Senior Research Scholar Contract No. RTA5780004.

\section{REFERENCES}

1. MacKenzie KJD, Welter M (2014) Geopolymer (aluminosilicate) composites: synthesis, properties and applications. In: Low IM (ed) Advances in Ceramic Matrix Composites, Woodhead Publishing, pp 445-70. 
2. Provis JL (2014) Geopolymers and other alkali activated materials: why, how, and what? Mater Struct 47, 11-25.

3. Provis JL, van Deventer JSJ (2009) Geopolymers: Structures, Processing, Properties and Industrial Applications, 1st edn, Woodhead Publishing.

4. Hanjitsuwan S, Hunpratub S, Thongbai P, Maensiri S, Sata V, Chindaprasirt P (2014) Effects of $\mathrm{NaOH}$ concentrations on physical and electrical properties of high calcium fly ash geopolymer paste. Cement Concr Compos 45, 9-14.

5. Hanjitsuwan S, Chindaprasirt P, Pimraksa K (2011) Electrical conductivity and dielectric property of fly ash geopolymer pastes. Int J Miner Metall Mater 18, 94-9.

6. Zhang Y, Liu L (2013) Fly ash-based geopolymer as a novel photocatalyst for degradation of dye from wastewater. Particuology 11, 353-8.

7. Forsgren J, Pedersen C, Strømme M, Engqvist H (2011) Synthetic geopolymers for controlled delivery of oxycodone: adjustable and nanostructured porosity enables tunable and sustained drug release. PLoS ONE 6, e17759.

8. Abdullah D, Pitt Ford TR, Papaioannou S, Nicholson J, McDonald F (2002) An evaluation of accelerated Portland cement as a restorative material. Biomaterials 23, 4001-10.

9. Zhang Y, Wang D, Wang F, Jiang S, Shu Y (2015) Modification of dicalcium silicate bone cement biomaterials by using carboxymethyl cellulose. $J$ Non Cryst Solid 426, 164-8.

10. Coleman NJ, Nicholson JW, Awosanya K (2007) A preliminary investigation of the in vitro bioactivity of white Portland cement. Cement Concr Res 37, 1518-23.

11. Hench LL (1991) Bioceramics: From Concept to Clinic. J Am Ceram Soc 74, 1487-510.

12. Hench LL, Andersson Ö (1993) Bioactive glasses. In: Hench LL, Wilson $\mathrm{J}$ (eds) An Introduction to Bioceramics, World Scientific, Singapore, pp 41-62.

13. Kokubo T, Takadama H (2006) How useful is SBF in predicting in vivo bone bioactivity? Biomaterials 27, 2907-15.

14. Hench LL (1998) Biomaterials: a forecast for the future. Biomaterials 19, 1419-23.

15. Fahami A, Nasiri-Tabrizi B, Ebrahimi-Kahrizsangi $R$ (2013) Mechanosynthesis and characterization of chlorapatite nanopowders. Mater Lett 110, 117-21.

16. Gallego D, Higuita N, Garcia F, Ferrell N, Hansford DJ (2008) Bioactive coatings on Portland cement substrates: surface precipitation of apatite-like crystals. Mater Sci Eng C 28, 347-52.

17. Martin S, Derrien AC, Oudadesse H, Chaucel-Lebret D, Cathelineau G (2005) Implantation of aluminosilicate/calcium phosphate materials: Influence on bone formation in rabbit tibias. Eur Cell Mater 9, Suppl. 1, 71-2.
18. Oudadesse H, Derrien AC, Martin S, Chaair H, Cathelineau G (2008) Surface and interface investigation of aluminosilicate biomaterial by the "in vivo" experiments. Appl Surf Sci 255, 593-6.

19. Leivo J, Meretoja V, Vippola M, Levänen E, Vallittu P, Mäntylä TA (2006) Sol-gel derived aluminosilicate coatings on alumina as substrate for osteoblasts. Acta Biomater 2, 659-68.

20. Todea M, Vanea E, Bran S, Berce P, Simon S (2013) XPS analysis of aluminosilicate microspheres bioactivity tested in vitro. Appl Surf Sci 270, 777-83.

21. MacKenzie KJD, Rahner N, Smith ME, Wong A (2010) Calcium-containing inorganic polymers as potential bioactive materials. $J$ Mater Sci 45, 999-1007.

22. Todea M, Frentiu B, Turcu RFV, Berce P, Simon S (2012) Surface structure changes on aluminosilicate microspheres at the interface with simulated body fluid. Corrosion Sci 54, 299-306.

23. Catauro M, Bollino F, Papale F, Lamanna G (2014) Investigation of the sample preparation and curing treatment effects on mechanical properties and bioactivity of silica rich metakaolin geopolymer. Mater Sci Eng C 36, 20-4.

24. Oudadesse H, Derrien AC, Lefloch M, Davidovits J (2007) MAS-NMR studies of geopolymers heattreated for applications in biomaterials field. $J$ Mater Sci 42, 3092-8.

25. Torkittikul P, Chaipanich A (2012) Optimization of calcium chloride content on bioactivity and mechanical properties of white Portland cement. Mater Sci Eng C 32, 282-9.

26. Rattanasak U, Pankhet K, Chindaprasirt P (2011) Effect of chemical admixtures on properties of highcalcium fly ash geopolymer. Int $J$ Miner Metall Mater 18, 364-9.

27. Škvára F, Šmilauer V, Hlaváček P, Kopecký L, Cílová Z (2012) A weak alkali bond in (N, K)-A-S-H gels: evidence from leaching and modeling. Ceram Silikáty $56,374-82$.

28. O'Connor SJ, MacKenzie KJD, Smith ME, Hanna JV (2010) Ion exchange in the charge-balancing sites of aluminosilicate inorganic polymers. $J$ Mater Chem 20, 10234-40.

29. Van Deventer JSJ, Provis JL, Duxson P (2012) Technical and commercial progress in the adoption of geopolymer cement. Miner Eng 29, 89-104.

30. Ridtirud C, Chindaprasirt P (2007) Calcined Ranong kaolin geopolymer mortar. Khon Kaen Univ Eng $J$ 34, 231-42. [in Thai]

31. Shiozawa M, Takahashi H, Iwasaki N, Uo M (2013) Effect of calcium chloride solution immersion on surface hardness of restorative glass ionomer cements. Dent Mater J 32, 828-33.

32. Shiozawa M, Takahashi H, Iwasaki N, Wada T, Uo M (2014) Effect of immersion time of restorative glass ionomer cements and immersion duration in calcium 
chloride solution on surface hardness. Dent Mater 30 e377-83.

33. Greenspan DC, Zhong JP, LaTorre GP (1994) Effect of surface area to volume ratio on in vitro surface reactions of bioactive glass particulates. In: Andersson ÖH, Yli-Urpo A (eds) Bioceramics, Proceedings of the 7 th International Symposium on Ceramics in Medicine, Turku, Finland, pp 55-60.

34. ASTM C109 (2002) Standard test method of compressive strength of hydrualic cement mortars (using 2-in. or [50-mm] cube speciments), ASTM International, West Conshohocken, PA 04.01.

35. Liew YM, Kamarudin H, Mustafa Al Bakri AM, Bnhussain M, Luqman M, Khairul Nizar I, Ruzaidi CM, Heah CY (2012) Optimization of solids-to-liquid and alkali activator ratios of calcined kaolin geopolymeric powder. Construct Build Mater 37, 440-51.

36. Yunsheng Z, Wei S, Zongjin L (2010) Composition design and microstructural characterization of calcined kaolin-based geopolymer cement. Appl Clay Sci 47, 271-5.

37. Zuhua Z, Xiao Y, Huajun Z, Yue C (2009) Role of water in the synthesis of calcined kaolin-based geopolymer. Appl Clay Sci 43, 218-23.

38. Pangdaeng S, Phoo-ngernkham T, Sata V, Chindaprasirt P (2014) Influence of curing conditions on properties of high calcium fly ash geopolymer containing Portland cement as additive. Mater Des 53, 269-74.

39. Xu H, Van Deventer JSJ (2000) The geopolymerisation of alumino-silicate minerals. Int $J$ Miner Process 59, 247-66.

40. Dorozhkin SV (2010) Bioceramics of calcium orthophosphates. Biomaterials 31, 1465-85.

41. Raynaud S, Champion E, Bernache-Assollant D, Thomas P (2002) Calcium phosphate apatites with variable $\mathrm{Ca} / \mathrm{P}$ atomic ratio I. Synthesis, characterisation and thermal stability of powders. Biomaterials 23, 1065-72.

42. Wang XJ, Li YC, Lin JG, Yamada Y, Hodgson PD, Wen CE (2008) In vitro bioactivity evaluation of titanium and niobium metals with different surface morphologies. Acta Biomater 4, 1530-5.

43. Li P, Ohtsuki C, Kokubo T, Nakanishi K, Soga N, Nakamura T (1992) Apatite formation induced on silica gel in a simulated body fluid. J Am Ceram Soc 75, 2094-7.

44. Arsad MSM, Lee PM, Hung LK (2011) Synthesis and characterization of hydroxyapatite nanoparticles and $\beta$-TCP particles. In: 2nd International Conference on Biotechnology and Food Science, IPCBEE, vol 7, IACSIT Press, Singapore, pp 184-8.

45. Catauro M, Bollino F, Kansal I, Kamseu E, Lancellotti I, Leonelli C (2012) Mechanical and biological characterization of geopolymers for potential application as biomaterials. AZojomo, doi: 10.2240/azojomo0322.
46. Chaipanich A, Torkittikul P (2011) Microstructure: surface and cross-sectional studies of hydroxyapatite formation on the surface of white Portland cement paste in vitro. Appl Surf Sci 257, 8385-90.

47. Gu YW, Khor KA, Cheang P (2004) Bone-like apatite layer formation on hydroxyapatite prepared by spark plasma sintering (SPS). Biomaterials 25, 4127-34.

48. Zhong JP, Greenspan DC, Feng JW (2002) A microstructural examination of apatite induced by bioglass in vitro. J Mater Sci Mater Med 13, 321-6.

49. Medri V, Papa E, Landi E (2013) Behavior of alkali bonded silicon carbide foams in modified synthetic body fluid. Mater Lett 106, 377-80.

50. Radev L, Hristov V, Michailova I, Samuneva B (2009) Sol-gel bioactive glass-ceramics. Part II: glassceramics in the $\mathrm{CaO}-\mathrm{SiO}_{2}-\mathrm{P}_{2} \mathrm{O}_{5}-\mathrm{MgO}$ system. Cent Eur $J$ Chem 7, 322-7.

51. Cao DG, Su DG (2005) Structure characterization for the geopolymer of sodium silicate and metakaolin. $J$ Chongqing Univ 4, 70-3.

52. Kim HM, Himeno T, Kokubo T, Nakamura T (2005) Process and kinetics of bonelike apatite formation on sintered hydroxyapatite in a simulated body fluid. Biomaterials 26, 4366-73.

53. Branda F, Fresa R, Costantini A, Buri A (1996) Bioactivity of $1.25 \mathrm{CaO} \cdot \mathrm{SiO}_{2}$ glass: an FTIR and Xray study on powdered samples. Biomaterials 17, 2247-51.

54. Ohtsuki C, Kamitakahara M, Miyazaki T (2009) Bioactive ceramic-based materials with designed reactivity for bone tissue regeneration. $J$ Roy Soc Interface 6, S349-60.

55. Li HC, Wang DG, Hu JH, Chen CZ (2014) Influence of fluoride additions on biological and mechanical properties of $\mathrm{Na}_{2} \mathrm{O}-\mathrm{CaO}-\mathrm{SiO}_{2}-\mathrm{P}_{2} \mathrm{O}_{5}$ glass-ceramics. Mater Sci Eng C 35, 171-8.

56. Prokopowicz M, Szewczyk A, Sawicki W (2014) The bioactivity studies of drug-loaded mesoporous silica-polydimethylsiloxane xerogels using FTIR and SEM/XEDS. J Mol Struct 1056-7, 262-6.

57. Torkittikul P, Chaipanich A (2009) Investigation of the mechanical and in vitro biological properties of ordinary and white Portland cements. Sci Asia 35, 358-64. 